NBER WORKING PAPER SERIES

\title{
JUDICIAL RISK AND CREDIT MARKET PERFORMANCE: MICRO EVIDENCE FROM BRAZILIAN PAYROLL LOANS
}

\author{
Ana Carla A. Costa \\ Joao M.P. De Mello \\ Working Paper 12252 \\ http://www.nber.org/papers/w12252
NATIONAL BUREAU OF ECONOMIC RESEARCH
1050 Massachusetts Avenue
Cambridge, MA 02138
May 2006

Forthcoming: Strengthening Global Financial Markets, Sebastian Edwards and Márcio G. P. Gracia, editors. Costa: ana.costa@bcb.gov.br.De Mello:jmpm@econ.puc-rio.br. Mrs Costa would like to stress that opinions expressed here are solely hers, and do not reflect any official position of the Brazilian Central Bank. Authors would like to thank Cornélio Pimentel, Daniel Sanchez and Plinio Romanini from DESIG/BCB for sharing the data. Johan Albino shared important informations about judicial disputes over payroll lending. We would also like to thank Tony Takeda, Marcelo de Paiva Abreu, Renato Flôres, Benny Parnes, and participants at the IASE-NBER conference for comments and suggestions. Usual disclaimer applies. The views expressed herein are those of the author(s) and do not necessarily reflect the views of the National Bureau of Economic Research.

(C2006 by Ana Carla A. Costa and Joao M.P. De Mello. All rights reserved. Short sections of text, not to exceed two paragraphs, may be quoted without explicit permission provided that full credit, including (C) notice, is given to the source. 
Judicial Risk and Credit Market Performance: Micro Evidence from Brazilian Payroll Loans Ana Carla A. Costa and Joao M.P. De Mello

NBER Working Paper No. 12252

May 2006

JEL No. L19, G21, D86, O16

\begin{abstract}
A large body of literature has stressed the institution-development nexus as critical in explaining differences in countries' economic performance. The empirical evidence, however, has been mainly at the aggregate level, associating macro performance with measures of quality of institutions. This paper, by relating a judicial decision on the legality of payroll loans in Brazil to bank-level decision variables, provides micro evidence on how creditor legal protection affects market performance. Payroll loans are personal loans with principal and interests payments directly deducted from the borrowers' payroll check, which, in practice, makes a collateral out of future income. In June 2004, a high-level federal court upheld a regional court ruling that had declared payroll deduction illegal. Using personal loans without payroll deduction as a control group, we assess whether the ruling had an impact on market performance. Evidence indicates that it had an adverse impact on risk perception, interest rates, and amount lent.
\end{abstract}

Joao M.P. De Mello

Departamento de Economia

Pontifícia Universidade Católica do Rio de Janeiro

Rua Marquês de São Vicente, 225

Rio de Janeiro RJ BRAZIL 22453-900

¡mpm@econ.puc-rio.br 


\section{Introduction}

In recent years, the literature has built a near consensus that "sound" institutions are congenial to good economic performance (North [1994]). Institutions, insofar as they determine the economic environment agents operate in, should be important for explaining economic outcomes. Quite often, the specific mechanism through which institutions influence economic performance is protection from expropriation. In environments in which expropriation is likely, agents underinvest (from a social perspective) relative to more secure ones. In the end, a plethora of sub-optimal microeconomic decisions amount to a poorer aggregate economic performance.

Indeed, most of the empirical effort in associating institutional "soundness", however defined, and economic performance has been on the aggregate level. An observation on a typical study is a country (La Porta et al. [1998A] is a seminal example). Institutional measures are then linked to economic performance on various dimensions. La Porta et al. [1998A], for example, document that the origin of the legal system is associated with the degree of creditor protection. La Porta et al. [1997] find that a lower degree of creditor protection implies smaller debt and equity markets. ${ }^{1}$ Another set of articles study the financial deepening-economic growth link (King and Levine [1993], Levine and Zervos [1998]), finding a positive relationship. Taken all together, these papers seem to imply the following chain of causality. At the basic level, legal origin (institution) cause creditor protection (protection from expropriation). At the second stage, better creditor protection cause financial deepening. Finally, financial deepening causes economic growth.

This chain of causality would be more convincing were microeconomic evidence available. The missing link is due to the level of analysis, much broader than the relevant locus of economic decisions. There is, for example, an implicit assumption that agents do invest less if creditors protection is lower. For several reasons, it is hard to be completely convincing with such an aggregate level of analysis. One such reason is reverse causality. The

\footnotetext{
${ }^{1}$ Pinheiro and Cabral [1998] follow this tradition for the Brazilian credit market. Using state-level data on outstanding volumes of credit, and an index of judicial efficiency (based on the results of a survey conducted with businessmen on each state where they rate the quality of the local judiciary), they relate variation in judicial inefficiency to differences in outstanding volumes of credit across the states. The authors conclude, corroborating the institution-development hypothesis, that improving the efficiency of judicial enforcement is important for credit markets development.
} 
following example, however farfetched, is illustrative. Assume investment is completely inelastic, and creditor protection is a superior good. Creditor protection, in this setting, has only distributive, not allocative, effects. For demand reasons, there is, however, a reverse causality running from income to creditor protection. Evidently, investment is not completely inelastic but the demand driven story is still conceivable. Most of the studies do recognize this possibility, and try to find sufficiently exogenous variation to relate institutions and economic performance. Acemoglu, Johnson and Robinson [2001] and Levine [1998] are good examples of careful searches for such variation.

Another problem stems from the fact that legal procedures are "chosen" by society, and hence may be endogenously designed to tackle the issues often put as the dependent variables in the regressions. La Porta et al [2003] face this difficulty. They argue that legal formalism reduces the quality of the judicial system. But formalism, as they recognize it, could also be a response to "weaker law and order environment". Their strategy is to use the fact that most countries inherit their legal tradition (and that French civil law is more "formalistic"), which makes the legal tradition a source of exogenous variation. Again, the story is compelling insofar as it is prohibitively costly for countries to "change" their legal tradition, since otherwise "maintenance" of tradition would itself be endogenous.

However well argued (as it is the case in all papers cited), identification is mostly a rethorical issue, since one can only test for overidentification. With micro level evidence, these issues can be bypassed, and one can directly assess how market participants respond to varying institutional environments. Creditor protection and financial deepening is an example. If there is evidence that creditors price judicial risk, or restrain quantities in face of weak protection, then it becomes much more compelling that legal protection induces financial deepening. In this case, one could be much more confident that the causality from creditor protection to income is of first-order, as opposed to demand driven explanations, such as protection being a superior good.

A third reason is omitted factors. Several other countries' characteristics might determine both institutional setting (such as legal origin and level of creditor protection, the usual explanatory variables) and economic performance (the usual regressand). Consider again the Acemoglu-JohnsonRobinson strategy for finding exogenous variation in institutional soundness 
to estimate the institution-economic performance link. ${ }^{2}$ For former colonies, one conceivable alternative story is the type of colonization. Suppose that, for sheer coincidence, while countries with a French civil law tradition (usually interpreted as "unsound" institutions) occupied lands that had valuables goods for the European market (silver in Peru and sugar in Brazil, for instance), countries with common law tradition ("sound" institutions) arrived at places that had few "tradable" goods with Europe (early English colonization of the US). Suppose as well that this trade feature determined how exploitative colonization was, and that exploitation had long lasting effects. In this case, the (omitted) driving force is whether there were comparative advantages to be explored. However, "sound" institutions and (later) economic performance would still relate empirically, although causal interpretation would not be warranted. We do not claim the institutional settings do not matter, and that the legal tradition only enters the picture through trade "causing" both institutional settings and economic performance. The crucial point is that, with micro level evidence, it is unnecessary to be concerned about such alternative explanations.

Finally, measurement is intrinsically more problematic with aggregate data. In La Porta et al. [1998], (country-level) creditor protection is measured by characteristics of the countries' corporate laws, and by several indices. ${ }^{3}$ Besides the inherent arbitrariness in constructing such indices, theory not always provides clear guidance in interpreting the results. For example, is it theoretically clear that restricting the behavior of managers always increases the amount of finance in equilibrium? It is conceivable that, if you sufficiently restrict managers' behavior, the size of debt and equity market will be small, for reasons pertaining to the supply of securities? Without a clear theoretical support, an empirical finding that restricting managers' behavior is associated with "larger" equity and debt markets is subject to criticisms that micro-evidence is not. One such criticism is the presence of non-linearities in the creditor protection-market performance relation. ${ }^{4}$

\footnotetext{
${ }^{2}$ Acemoglu, Johnson and Robinson [2001] document that "better institutions" arose in countries where mortality rates due to native diseases were low when colonizers originally arrived. This, according to the authors, shift the equation that determines institutions but not the equation that determines current economic performance.

${ }^{3}$ They have indices for, among others, efficiency of the judicial system, risk of expropriation, and risk of repudiation of contracts by government.

${ }^{4}$ Dubey, Geanakoplos and Shubik [2003] show that, with incomplete markets, that intermediate levels of debtor punishment can induce a larger quantity of credit that extreme
} 
It might seem puzzling the relative lack of micro evidence on the institutiondevelopment nexus. We conjecture that this is due to the scarcity of a fortunate coincidence: data on both the relevant economic decision locus (firms, consumers) linked to variation on institutional settings. La Porta et al. [2003] study on the formality of legal procedures and the quality of the legal system is somewhat an exception. ${ }^{5}$ They do not, however, directly associate market level performance with different institutional settings.

In this work, we take advantage of a particular set of events that provide variation on a relevant institutional setting and we are able to associate this variation with data on the relevant economic decision locus. The empirical setting is the market for Payroll Debit Loans in Brazil. Payroll Debit Loans are personal loans with principal and interests payments directly deducted from the borrowers' payroll check, which, in practice, makes a collateral out of future income. In June 2004, a high-level federal court upheld a regional court ruling that had declared payroll deduction illegal. ${ }^{6}$ The decision by the federal court has a case specific nature, i.e. only applies to this particular dispute. There is, however, evidence from market practioners that there was an increase in the perceived probability that the decision could establish precedent, and turn useless the future income collateral. Using personal loans without payroll deduction as a control group, a difference-in-difference procedure assess whether the judicial decision had an impact on market performance. As a preview, the data on bank level suggest that the decision had an adverse impact on banks' risk perception, on interest rates, and on the amount lent. In this sense, this is direct evidence of market participants' reaction to institutional risk.

Our theory is simple to the point of trivial: an increase in the chance of expropriating the collateral should shift the supply of loans inward, worsening market performance. Whether the empirical consequences are first order is far from trivial. This is, indeed, the goal of the paper: investigate whether a clear-cut shift in the institutional setting has microeconomic consequences. Evidence from market pratictioners is ambiguous. While some important

levels of debtor punishment.

${ }^{5}$ In this paper, the authors study the link between formality of the legal system and the time elapsed to evict non-paying tenants, and to recover a bounced check. Furthermore, they associate formality with other measures of judicial system performance, such as corruption, and access to justice.

${ }^{6}$ The court ruled at the very end of June (28th). However, the press release was on July 1 st. 
players had the perception that the decision could have strong adverse effects, equally important players thought the effect would be second order.

The market level evidence is a complement, not a substitute, to the aggregate level evidence. Indeed, our results in no way contradict the literature. On the contrary, they corroborate it. While aggregate evidence indicates that institutional differences are of first-order importance in explaining variation in countries' performances, micro and market level evidence evaluates directly the implicit assumption necessary to interpret the aggregate evidence as indeed causal.

The result has an additional interest given the empirical application. Payroll Lending is one of the workhorses of the recent Brazilian credit market expansion. Brazil, in La Porta-Lopez-Silanes-Shleifer-Vishny tradition, is a French civil law country, with low creditor protection. Credit markets are relatively underdeveloped. Recently, however, it has make several efforts towards a more creditor friendly institutional environment. Courts may be particularly important in an environment with weak creditor protection, where other protective institutions, such as laws, are weak or inexistent.

The paper is organized as follows. Section 2 outlines the recent evolution of credit market in Brazil and the chronology of Payroll lending, emphasizing the relevant events, such as the approval in congress of the law regulating Payroll Lending for retirees and the judicial decision on the legality of payroll deductions. Section 3 presents the data, and Section 4 the empirical strategy. We argue that the presence of an identical product, except for deduction in payroll, provides a good control for associating changes in the institutional environment to market changes in Payroll Lending. Results are presented and discussed in Section 5. Section 6 concludes.

\section{Credit Market in Brazil: Recent Evolution and Payroll Lending}

In recent years, bank lending experienced a pronounced increase in Brazil, specially in lending out of banks' "free lending funds" (those not earmarked by mandatory programs). Between July 1999 and September 2005, the free loans/GDP ratio went from $8.3 \%$ to $17.1 \%$ (Figure 1). This free loan segment now represents $67 \%$ of total banking credit, changing positions with directed 
credit operations- that now stands at $33 \%{ }^{7}$

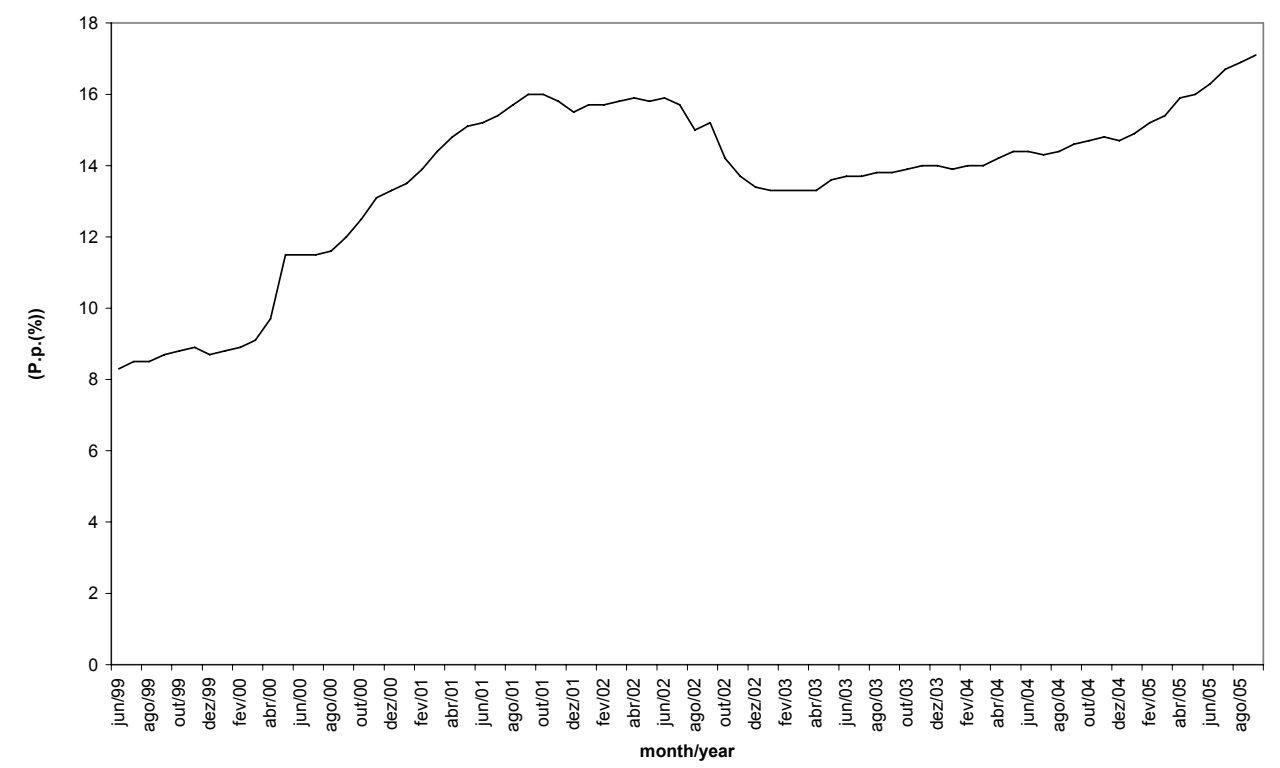

Figure 1: Private Banking Credit/GDP, 1999 to 2005 (Free Loans)

Interestingly, this tendency of financial deepening took place during a period of tight monetary policy ${ }^{8}$. Despite this fact, free market lending expanded remarkably. Several factors help explain this trend.

These specific factors are all linked to institutional reforms that took place in Brazil since the end of 1999. Measures included: efforts to reduce information asymmetries in credit markets (such as the new credit ranking and provisioning regulation, through Resolution 2.682/99, and the Central Bank Credit Information System (SCR), implemented in 1999 and improved in 2000 and 2004); more efficient instruments of collateral recognition and contract enforcement (as the so-called "Cédula de Crédito Bancário", a claim

\footnotetext{
${ }^{7}$ Numbers for December, 2005. Banking credit portfolios in Brazil have two types of loans: free market operations, where banks can set quantity and prices according to their profit maximizing behaviour; and compulsory directed credit operations - mostly channeled to housing and rural sectors at subsidized interest rates.

${ }^{8}$ Brazil adopted Inflation Target and Floating Exchange Rate regimes in 1999 during a liquidity crisis, exchange rate devaluation and inflation pressure. Interest rates where the main instrument used to stabilize the economy. Inflation targets are set by Nacional Monetary Council and basic interest rates are monthly defined by Central Bank in Monetary Policy Comittee (COPOM) meetings.
} 
with faster execution procedures, in 2001 and 2004) ${ }^{9}$; a better insolvency resolution system (through a new bankruptcy law, approved by Congress in the end of 2004); and regulation of creative credit instruments, such as payroll lending. They provided an improved institutional environment and possibly led to the observed higher volumes of credit concessions by the Brazilian banking sector. As suggested in the previous cited literature, the evolution towards a more creditor friendly environment might have engendered this initial movement of financial deepening in Brazil.

Nevertheless, this rapid expansion path - more pronounced during the last two years - is not observed in all credit market segments. On the contrary, this acceleration is mainly explained by growing volumes of consumer loans. Credit to this segment, which in 1999 represented $3.6 \%$ of GDP (or 9\% of total private bank credit portfolio), reached in 2005 outstanding volumes that amount $8.7 \%$ of GDP (or $31 \%$ of total private bank credit portfolio). Consequently, since December 2004, personal loans respond for the biggest part of total bank loans, with an even higher participation than industrial credit, that has been stable around $6.9 \%$ of GDP (Figure 2).

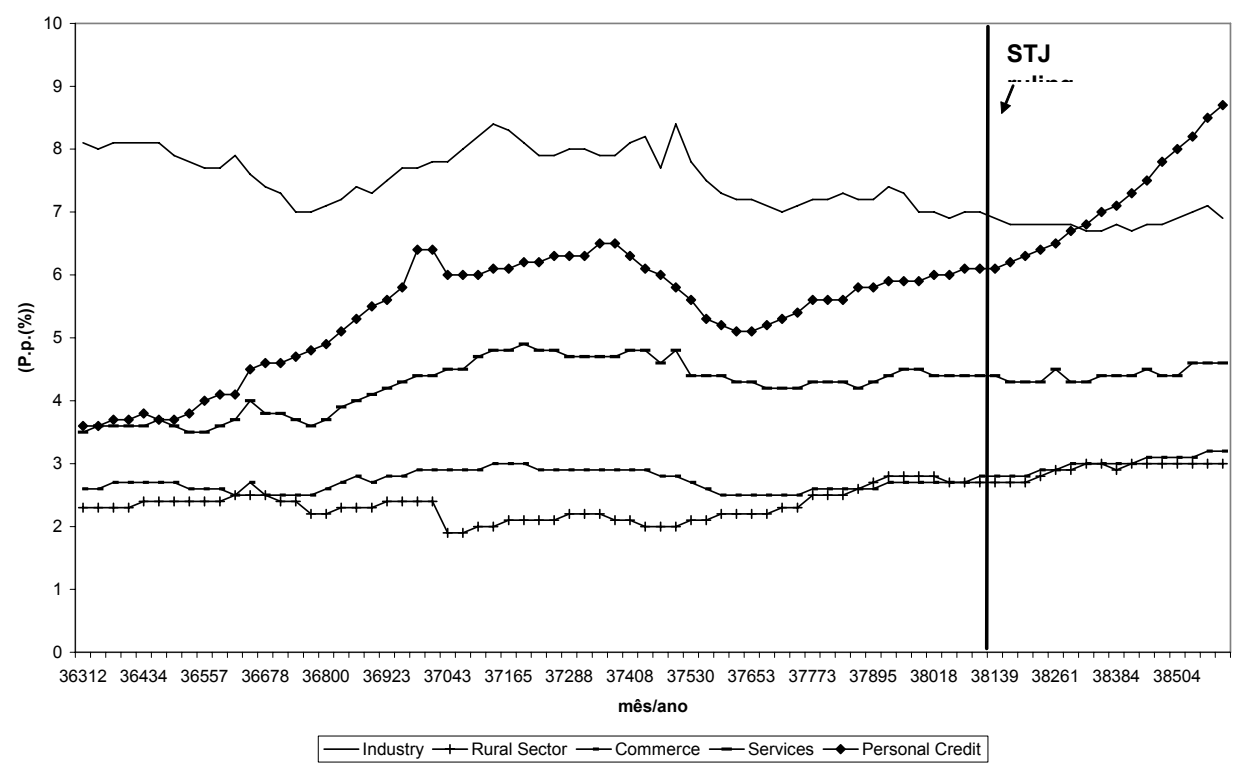

Figure 2: Private Banking Credit/GDP - Evolution by Economic Segment (1999 to 2005)

\footnotetext{
${ }^{9}$ The SCR brings detailed information on borrower's credit contracts of over $\mathrm{R} \$ 5,000.00$. (roughly $\mathrm{U} \$ 2,200.00$ ).
} 
Consumer credit loans in Brazil can be divided into three main types of loans. The personal loan, for consumption purposes; loans for vehicle acquisition; and Cheque Especial, a consumer overdraft facility. It is, however, in the personal loan category - the largest category, that a major growth is observed (52\% during the last twelve months), as showed in Figure 3.

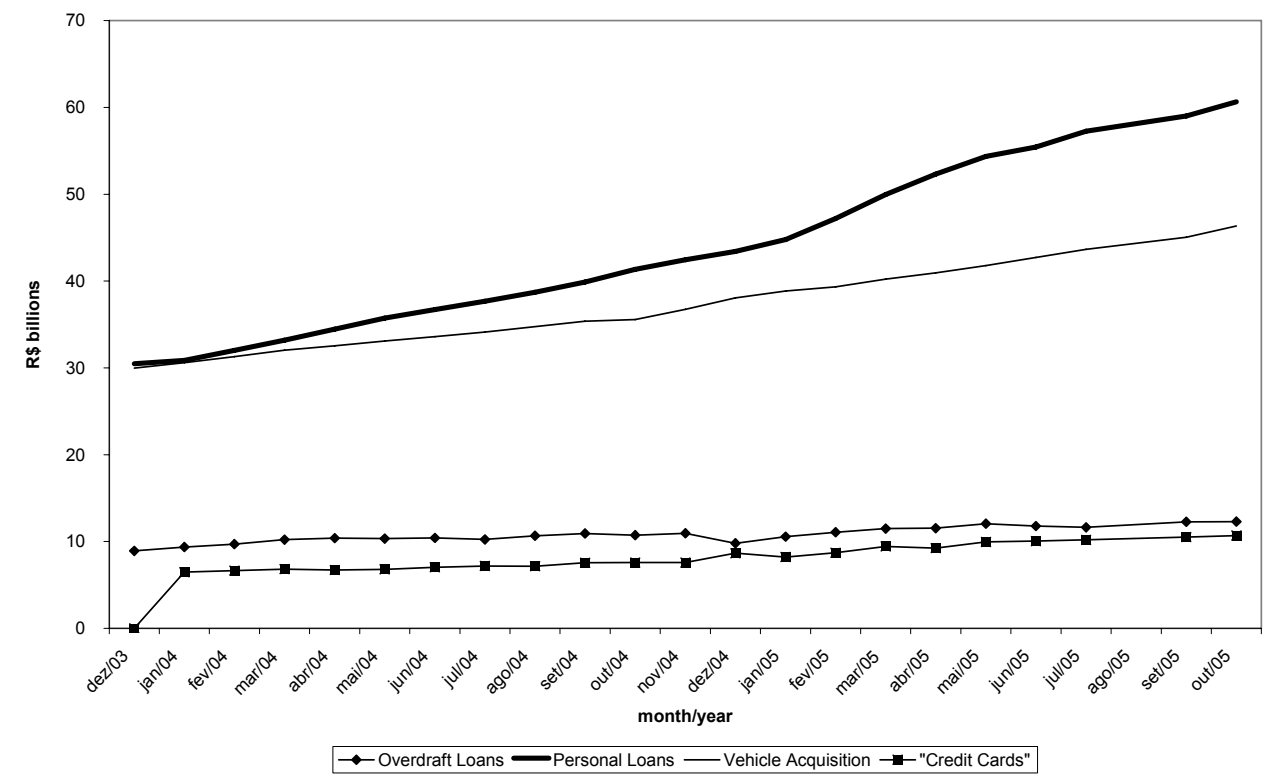

Figure 3: Personal Lending in Brazil

This paper is concerned with personal loans, which are further divided into two sub-categories: the standard loan contract (hereafter standard loan), and a special type of personal loan contract that has an automatic monthly payment deducted from the borrower's salary. This is the payroll lending operation (Crédito Consignado em Folha de Pagamento, hereafter payroll loan), which represents over $35 \%$ of all consumer credit in Brazil, and whose growth path has shown a particularly noticeable increase. Figure 4 shows the evolution of payroll lending operations, and its increasing participation on total personal loans, for the thirteen largest active banks in this segment. ${ }^{10}$

\footnotetext{
${ }^{10}$ Brazilian Central Bank collects this data for this small - but representative - sample of banks since January 2004. It now aims to expand it to all banks operating with this specific type of credit.
} 


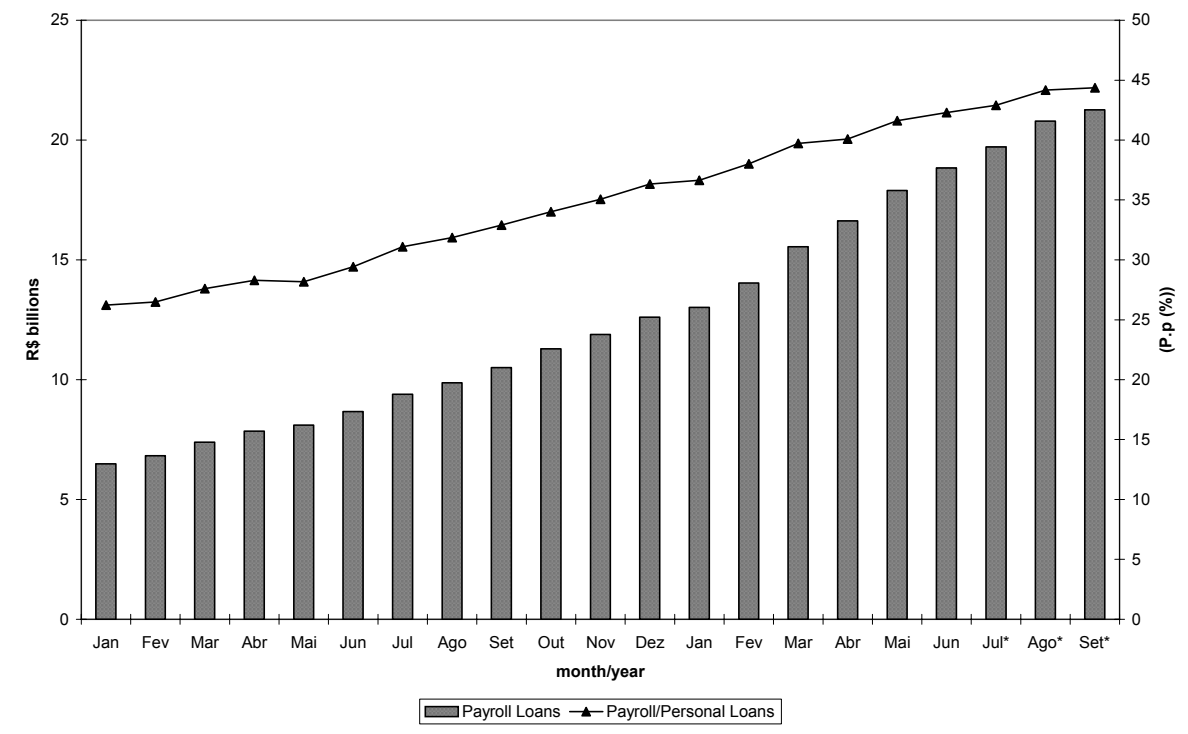

Figure 4: Personal Lending in Brazil

Payroll lending exists in Brazil since the beginning of the 1990s. It was restricted to government personnel and was originally operated by peculium institutions, which had the possibility to act as trusts before public administration agencies. ${ }^{11}$ But since the second half of the 1990s some financial institutions identified in this type of loan a good business opportunity, with low credit risk and high return. Those banks entered this credit market through the acquisition of peculium institutions already registered as trustees.

\subsection{Payroll Loans: Description of the Product, Chronol- ogy of Events, and Pratictioners' Opinions}

The decisive expansion of payroll lending operations occurred in September 2003, when the government sent to Congress a provisory law (Medida Provisória (MP) 130), subsequently turned into Law $10.820 / 03 .^{12}$ The law regulated the possibility of salary consignation for private sector formal workers, and for retired workers from private sector and pensionaries covered by

\footnotetext{
${ }^{11}$ Law 8.112/90 admits the possibility of payroll consignation for government personnel.

${ }^{12}$ Medida provisória is a legislative device in which the executive sends a bill to congress that is effective immediatly, pending approval. It has an urgency status that forces the legislator to appreciate its merit. For practical purposes, it is almost equivalent to a full-blown law.
} 
the National Institution of Social Security (INSS). ${ }^{13}$

In practice, payroll deduction turns future income into collateral. Evidently, future income is valuable as a collateral insofar as it is not too volatile. This is precisely why payroll lending is mainly used for the following three types of borrowers. Before the 2003 law extended regulation to private sector retirees, banks lent to public servants, which have employment stability. Banks then started operating with private sector workers, but in association with the labor unions and employers. Contracts are collective, which mitigates idiosyncractic income risk. Finally, after the December 2003 law, banks started operations with retirees from the private sector, which also have a constant income flow. The main risk lenders face is death, which is diversifiable and insurable.

Lenders, however, face another peril: judicial risk. Collateral has value only if courts recognize it as such. Payroll lending in Brazil provides an excellent empirical setting to assess judicial risk. In 2002, a public servant of the city of Porto Alegre (the capital of the state of Rio Grande do Sul) sued Banco Sudameris claiming the payroll deduction on his salary was illegal. ${ }^{14}$ A state-level court (Tribunal de Justiça do Rio Grande do Sul) ruled for the plaintiff. The decision did not draw much attention for two reasons. First, by that time, payroll lending was not such an important credit instrument. Second, the decision did not set a precedent, once it was related to a claim that started before the 2003 law, and had been ruled by a state-level court. Sudameris appealed to the second highest ranking federal court in the country, the Superior Tribunal de Justiça (STJ). ${ }^{15}$ In late June 2004, the STJ upheld the regional court ruling. Although technically this decision also did not set precedent on the issue, it could signal the direction of future rulings. ${ }^{16}$ In this case, the future income collateral could become useless. At the time, Minister Edson Vidigal, from the STJ, declared that "...[when] an-

\footnotetext{
${ }^{13}$ The Brazilian pension system, a pay-as-you-go scheme, is publicly managed by this governmental agency, INSS.

${ }^{14}$ The deduction was $\mathrm{R} \$ 58.66$ (roughly $\mathrm{U} \$ 22$ by then), to cover amortization and interest expenses on a $\mathrm{R} \$ 1.015$ loan. The precise claim was that wages are essential for subsistence, and therefore cannot be pawned. Furthermore, the monthly nominal interest rate of $3.8 \%$ was ruled "abusive". See Valor Econômico 07/02/2004. For the actual decision, see the STJ website, http://www.stj.gov.br.

${ }^{15}$ Hierarchically, the STJ stands between the STF (Supremo Tribunal Federal), the equivalent of the American Supreme Court, and the TFJs (Tribunais Federais de Justiça), equivalent to the American Federal Circuit Courts.

${ }^{16} \mathrm{STJ}$ rulings are case specific, and do not set precedent.
} 
alyzed through the salary perspective, the consignation can be suspended," and "[banks] might have to search for alternative forms of guarantees."17

Statements by some key pratictioners suggest that banks perceived this as a hazard to their payroll loans operations. Right after the decision, the Chief of Judicial Operations of Federação Brasileira de Bancos (FEBRABAN, the main bankers's association), Johan Albino Ribeiro, declared to the press that "... undoubtedly there will be a repercussion in terms of higher interest rates" since "...[one] of the elements that sustain the low interest rates is the low risk on these loans. If the legality of the contract is contested, the risk increases". ${ }^{18}$ Luís Marinho, then the head of Central Única dos Trabalhadores (CUT), the main workers's union, reported that he had received phone calls from several bankers informing "...[that] banks would hit the break on new loans, at least temporarily, until they have a better understanding of the extension of the STJ decision." 1920

However, whether banks indeed reacted to the decision in an economically meaningful way is not obvious. Indeed, it was not even clear whether, legally, the court ruling would have a lasting effect. As it was noted, the decision only applied to one specific claim, related to a public servant and which took place before the December 2003 formal regulation. Therefore the STJ decision could not, technically set precedent for future lawsuits. Several banking lawyers thought the law regulating payroll loans (Law 10.820/03) was crystal clear. ${ }^{21}$ In this sense, all the decision could signal was the courts' mood toward payroll loans. Furthermore, banks could have simply ignored it. Indeed, Gabriel Jorge Ferreira (a former head of FEBRABAN), from UNIBANCO (the third largest private bank in Brazil), declared that "... [the program] is still intact, and I do not think there will be an upward pressure in interest rates." ${ }^{22}$ Indeed, this is precisely our object of study: whether there is evidence that this judicial hazard had a first-order impact on market performance. In our application, an affirmative answer would be even more meaningful given the ambiguity of both the (practical) legal consequences of the ruling, and the bankers' reactions. As figure 4 shows, it is clear that the court ruling has not prevented the recent growth of payroll loans. There

\footnotetext{
${ }^{17}$ See Gazeta Mercantil, 16/07/2004.

${ }^{18}$ See Valor Econômico, 07/02/2004.

${ }^{19} \mathrm{Mr}$. Marinho would later be appointed Minister of Labor.

${ }^{20}$ See Universo Online, 07/04/2004, http://an.uol.com.br/2004/jul/04/0eco.htm

${ }^{21}$ See Valor Econômico, 07/02/2004, 08/13/2004.

${ }^{22}$ See Universo Online, 07/04/2004, http://an.uol.com.br/2004/jul/04/0eco.htm
} 
is, nonetheless, a couple of interesting contrafactual questions left to ask. Absent the decision, would this growth have been more pronounced? Would terms be better (i.e. lower interest rates)?

\section{Data}

Using original data from Central Bank Credit Information System (SCR), we constructed a data set on payroll and standard loans. For both types of credit contracts we have bank level monthly data over a period starting on January 2003 and ending on May 2005. There is, initially, data for 109 active banks on outstanding volumes of payroll and standard personal lending operations. We have bank-level information on: the total amount of loans; average risk rating; average interest rate; number of credit contracts; and average size of the credit contract ${ }^{23}$

The data has information on loan contracts above $\mathrm{R} \$ 5,000(\mathrm{U} \$ 2,270)$. An average sized contract is $\mathrm{R} \$ 84,719$ (U\$38,508) This strongly indicates that contracts in the data are mainly indirect, i.e., with entities such as labor unions and governmental agencies, which intermediate the negotiation, and afterwards refer the bank to their employees or members. Contracting directly with individuals began mostly after the December-2003 law, which regulated payroll lending to private sector retirees. Since it took at least another 5 months for a significant group of banks to be chartered by National Institution of Social Security (INSS), the fact that these loans do not show in our data is relatively immaterial. ${ }^{24}$

In order to keep consistency among observations, banks had to satisfy several criteria to be part of the final sample used. First, only banks that consistently operated in both credit products were included. This avoids picking up unrelated (to the court ruling) entry and exit decisions, which are but noise for our purposes. Only banks that supplied both standard and payroll loans for the whole Jan/04-Dec/04 period were included. Second, banks that had inconsistent pricing behavior were excluded. For example, several banks

\footnotetext{
${ }^{23}$ Interest rate is weighted by the volume of new concessions at each risk category. Credit risk rating goes from 1 (or AA operations: less risk) to 10 (or $\mathrm{HH}$ operations: maximum risk), following provisioning and classification criteria set by Nacional Monetary Council regulation.

${ }^{24}$ The December-2003 law required the bank to be chartered by the INSS in order to supply payoll lending to private sector employees. The first bank to be charted was the Caixa Econômica Federal (a federal government bank), in May 2004.
} 
had annual nominal interest rates at $12 \%$, which are clearly out of line with the rest of the market. $12 \%$ operations are either reporting errors, or special loans such as those to own employees, which we conjecture to have a different risk assessment nature. Other banks had inconsistent structural breaks on the interest rate series ${ }^{25}$. Finally, it is not clear whether government-owned banks (both state and federal) have the same objective function as their private counterparts. The literature is ambiguous with this respect. Although some works suggest that there is no evidence that public owned banks are less efficient than private counterparts (Altubas et al. [2001]), there is little controversy over their different lending behavior (Sapienza [2002]). And, for Brazil, even if government-owned banks had the same objective function as private banks, payroll loans is an important piece of policy for the current federal government, and federally owned banks might be responding to public policy rather than maximizing profits regarding payroll loans. ${ }^{26}$ For these reasons, government-owned banks.were excluded.

After these adjustments, the sample consists of 40 banks, representing $67.8 \%$ of total payroll lending volumes as of May 2005. The sample includes 4 out the 5 major private Brazilian banks.

\section{Empirical Strategy}

The opinions voiced by market participants in the press suggest the three economic variables that might have been affected by the June 2004 STJ ruling: risk assessment, the pricing of loans, and the amount lent. The empirical strategy consists in comparing the evolution, over a period of time that contains the ruling, of two products: payroll and standard loans. The

\footnotetext{
${ }^{25}$ It is important to emphasize that we identified some problems with the interest rate variable in SCR data set. For this reason we are less confident about the interest rate results than the other results presented in Section 5. The SCR regulation states that interest rates must be reported on a yearly basis. Nevertheless, not only inconsistent numbers such as zero or very low rates abound, but also rates that seem to be monthly or contract period based systematically appear. Those observations were discarded.

${ }^{26}$ Non-profit maximizing behavior should not come as a surprise in Brazil when analysing public banks portfolio. Banco do Brasil (BB) and Caixa Econômica Federal (CEF), the two largest government-owned banks are, respectively, the major players in rural and housing subsidized credit. BB outstanding rural credit portfolio represents $52 \%$ of all directed and subsidized rural credit in Brazil. CEF, as of January 2005, accounted for $42 \%$ of total subsidized housing finance operations in Brazil.
} 
difference in their evolution over the period is interpreted as the causal effect of the STJ decision, as in a difference-in-difference model.

\subsection{The Control Group}

As mentioned in Section 2, although payroll lending exists since 1990, only in December 2003, legislation regulating its application to private sector formal workers and retirees and pensionaries of social security system was passed. Moreover, only since January 2003 we have available - and good quality split data on payroll and standard personal loans.

The object of interest is a supply effect: has the court decision shifted the supply of payroll loans? We do not, however, pursue the strategy of searching for exogenous variation to estimate the supply directly. As it will become clear below, a reduced-form object is estimated for price, risk, and quantity. The strategy consists of using standard loans as a control group. This way, one can gauge the effect of the court decision above and beyond unobserved concurrent factors that might have affected both the demand and supply of payroll loans. ${ }^{27}$

Standard loans are a reasonable control group for payroll loans. The two products are the same, with the exception of the payroll deduction ${ }^{28}$. That is, both products are personal lending operations, consumption oriented and have no formal collateral or real guarantee attached to. Finally, since standard loans do not have payroll deduction, they were not directly affected by the June 2004 court ruling.

A fair question is why standard loans exist at all given the presence of an apparently superior very similar credit instrument. As a matter of regulation, payroll loans were confined to special classes of borrowers up until the December 2003 law, and the subsequent chartering of banks to provide these loans on a more general basis. ${ }^{29}$ In particular, it could be the case that public sector employees were significantly more present in payroll vis-à-vis standard loans. This, however, does not seem to be the case, especially for

\footnotetext{
${ }^{27}$ We do not have overall demand shifters, that is, exogenous variation to estimate the supply. Let alone, product specific (to payroll loans, for instance) demand shifters. For example, there is no compelling economic reason why seasonality (a candidate) would affect payroll loans differently than standard loans.

${ }^{28}$ As a matter of regulatory taxonomy, standard and payroll loans are two subcategories of personal loans.

${ }^{29}$ See section 2 .
} 
our specific sample: payroll lending with the observed average size consists of both private sector employees (through agreements with private companies or professional associations) and public servents.

While differences in the composition of the pool of borrowers is not a threat to our identification strategy, whether these two pools of borrowers changed differently over the sample period is. There are two reasons why this does not seem to be the case. First, the main change in composition of the pool of borrowers occurred during 2005, when banks started getting chartered by the Social Security Agency to lend to private sector retirees. Therefore there were no significant changes in the compositions of the pool of borrowers in the two groups. Second, economic conditions could have changed differently for the two groups, holding constant the composition of both pools. This would happen if, for instance, the public sector was downsizing at the time, or if the private formal sector was experiencing a particularly turbulent period. Neither were the case.

\section{Summary Statistics}

\begin{tabular}{|c|c|c|c|c|c|}
\hline & & & & Standar & Deviation \\
\hline & & Whole Period & $\begin{array}{c}\text { Sub- } \\
\text { Sample:month } \\
>12 \text { and }<18\end{array}$ & Whole Period & $\begin{array}{c}\text { Sub- } \\
\text { Sample:month } \\
>12 \text { and }<18\end{array}$ \\
\hline 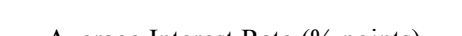 & Treatment: Payroll & 45.07 & 46.08 & 12.21 & 8.80 \\
\hline Average Interest Rate ( $\%$ points) & Control: Standard & 56.67 & 53.93 & 24.62 & 26.05 \\
\hline Totol A mountof Lonc (DC) & Treatment: Payroll & $6.83 \mathrm{E}+07$ & $5.93 \mathrm{E}+07$ & $1.38 \mathrm{E}+08$ & $1.13 \mathrm{E}+08$ \\
\hline Total Amount of Loans (R\$) & Control: Standard & $6.54 \mathrm{E}+07$ & $5.90 \mathrm{E}+07$ & $1.43 \mathrm{E}+08$ & $1.19 \mathrm{E}+08$ \\
\hline 1 & Treatment: Payroll & 2.51 & 2.63 & 0.55 & 0.66 \\
\hline Average Risk (from categories I to 10) & Control: Standard & 3.17 & 3.31 & 0.99 & 1.13 \\
\hline
\end{tabular}

TABLE 1: Source: Banco Central do Brasil. Sub-sample of 40 banks included in the regression analysis. Market averages, weighted by bank size of operations, except for total amount of loans.

Table 1 presents summary statistics on the variables that are used as regressands in the analysis below. As expected, the average interest rate is lower in payroll than in standard loans: the instruments are very similar and the former has wages as collateral. Similarly, standard loans are riskier, which is consistent with a higher voluntary - and involuntary - default probability. The amount lent in payroll loans is higher than in standard loans, and has increased more pronouncedly over the sample period. ${ }^{30}$

\footnotetext{
${ }^{30}$ For the thirteen banks of the sample mentioned in section 2 , granting of payroll loans increased by $66,7 \%$ during the last 12 months. Outstanding volumes more than doubled during the same period, while total personal loans increased by 50,1\% (NEI, BCB 2005).
} 
When one compares the summary statistics for the control and treatment groups, a few points emerge. First, for payroll loans, both interest rate and risk were slightly higher than average on the sub-period before the court ruling. For standard loans, the interest rate was below average, and risk was slightly above average. This is important for our purposes, since the different types of loans could be, on the months before the ruling, on different parts of a mean-reversing process. This does not appear to be the case, and, if anything, interest rates should tend to increase more (decrease less) for standard loans, vis-à-vis payroll loans, if a mean-reversing force is operative. Similarly for risk perception.

As for amount lent, one can see, from both table 1 and figure 4, an increase in both categories over the period, with a more pronounced increase for payroll loans. The two categories are following, over time, different paths, which could lower the value of standard loans as a control group. However, if anything, the pronounced upward trend in payroll loans would make it particularly difficult to document a decrease in payroll loans relative to standard loans.

\subsection{The Specifications}

The interest rate and the quantity models are quite similar. An observation is a product $i$, offered by a bank $b$, at a month $t$. There are two products, personal credit with and without payroll automatic debit. Let DECISION be a categorical variables that assumes the value 1 for July 2004 and all months later. It denotes the treatment period. ${ }^{31} P A Y R O L L$ is a categorical variable that assumes the value 1 if the product is personal loan with payroll deduction. It identifies the treatment group. The estimated model for the interest rate is:

$$
\begin{aligned}
& \Delta \log \left(\text { INTEREST }_{i t b}=\beta_{0}+\beta_{1}\right. \text { PAYROLL } \\
& +{ }_{i t b}+\beta_{2} \text { DECISION }_{t} \\
& +\beta_{3} \text { DECISION }_{t} \times \text { PAYROLL } L_{i t}+\Omega M O N T H_{t}+\text { Controls }+\varepsilon_{i t b}
\end{aligned}
$$

INTEREST $T_{i b t r}$ is the average interest rate on all loans given by bank $b$ on product $i$, at month $t$. The panel unit is a pair bank-product. We are interested in the level of log effect, but the data is first-differenced to eliminate

\footnotetext{
${ }^{31}$ Rigorously, the decision took place in June 2004. It was, however, at the very end of the month (the 28th), so banks only had time to react to it in July. Therefore, all estimated models consider the treatment period to start in July 2004.
} 
fixed effects of the pair bank-product. Controls include the log of the average risk on the banks' portfolios, the (lagged) total number of loan operations and the (lagged) average size of the loan operations. Risk is included for obvious reasons, since it should determine interest and is affected by the decision. Total number of loans is included because, as we have seen, payroll and nonpayroll loans have different rates of expansion over the sample period. Since expansion might affect the quality of the loan portfolio, the total number of operations should be controlled for. The average size of operations is included since it is conceivable that banks reacted to the judicial decision by decreasing exposure on operations by decreasing their size.

The main parameter of interest is $\beta_{3}$, the difference-in-difference coefficient. If the judicial decision had an impact on banks' pricing of payroll loans, then $\beta_{3}$ should be positive. We run a OLS procedure on this equation, with the two modifications. First, we weight observations by the size of banks' operations on payroll and standard loans, to arrive at an average market response. Second we correct for between panel correlation and within panel autocorrelation.

The model can be viewed as a reduced form, in which prices (in this case interest rates) are regressed on exogenous variables. As in any reduced form, there could be supply (which is of interest) and demand effects (not of interest) on the parameters. After controlling for period specific effects, estimates should be clean of most demand effects, and $\beta_{3}$, the main coefficient of interest, should capture a supply response to the ruling. Note that, precisely to mitigate capturing demand effects, we lag variables such total operations and average operations.

The quantity model is similar except that we do not control for the total number of operations and the average size of operations. We conjecture that these variables affect primarily the interest rate: ${ }^{32}$

$$
\begin{gathered}
\Delta \log (\text { Total Loans })_{i t b}=\beta_{0}+\beta_{1} \text { PAYROLL }_{i t b}+\beta_{1} \text { DECISION }_{t}+ \\
\beta_{3} \text { DECISION }_{t} \times \text { PAYROLL L } \text { S }_{i t}+\Omega M O N T H_{t}+\text { Controls }+\varepsilon_{i t b}
\end{gathered}
$$

The main control now is the first-difference in the log of average risk on the banks' portfolio. Again, the main parameter of interest is $\beta_{3}$, the difference-in-difference coefficient. If banks reacted to the judicial decision by restricting quantity, then $\beta_{3}$ should be negative. We estimate the parameters

\footnotetext{
${ }^{32}$ Results are similar whether total loans and average size of loans are included or not.
} 
by an OLS and an IV procedure. Differently from the interest rate equation, there is empirical reason to believe the lag of the dependent variable belongs to the right-hand side, and there is also reason to believe that there is serial correlation on the error term. In this case, OLS could produce inconsistent estimates (see Arellano and Bond [1991]). ${ }^{33}$ Similarly to the interest model, we weight observations by the size of banks' operations in personal lending, and standard errors are corrected for between correlation and within panel autocorrelation.

For the risk perception model, an observation is a product $i$, offered by a bank $b$, at a month $t$. In the first specification, the dependent variable, $R I S K_{i b t}$, is a dummy variable, that assumes the value 1 if the average risk on product $i$ loans given by bank $b$ at month $t$ is above the median risk for that bank over the period considered. In the second specification, $y_{i b t}$ is the average risk on product $i$ 's loans given the bank $b$ 's at month $t$. The estimated model is:

$$
\begin{aligned}
R I S K_{i t b}= & \beta_{0}+\beta_{1} P A Y R O L L_{i b t}+\beta_{2} D E C I S I O N_{t}+ \\
+ & \beta_{3} \text { DECISION } \times \text { PAYROLL } L_{i b t}+ \\
& \text { Controls }+\Omega M O N T H_{t}+\varepsilon_{i b t}
\end{aligned}
$$

CONTROL $S_{b i t}$ are variables that affect risk (such as average size of loans and total number of loans). In this case it is unnatural to first-difference the data to eliminate fixed-effects, we include bank dummies. Again, the main coefficient of interest is $\beta_{3}$, the difference-in-difference coefficient. If the judicial decision had an impact on banks' risk perception on Payroll Loans, then $\beta_{3}$ should be positive: risk assessment on payroll loans increased compared to standard loans We run a Logit procedure on this equation, again weighting observations by the size of banks' operations in personal lending.

Notice that in all models, variation among banks is used. This is crucial, since the main economic decision unit is a bank. Although the judicial decision hit banks at the same time (DECISION $N_{t}$ does not vary over $\left.b\right)$, banks potentially differ in their response to the decision, and this provides variation

\footnotetext{
${ }^{33}$ Several economic stories could be told to justify the lag of $\Delta \log$ (Total Loans) to belong, or not, to the right-hand side of both the interest and the quantity equations. Since this is not our variable of interest, we take an agnostic empirical approach, and evaluate whether empirically it belongs to the equation and take proper econometric steps to correct (i.e., look for exogenous variation) if it does.
} 
to estimate the coefficient of interest. In the end, the response of an average bank is estimated, with larger banks counting more than smaller ones.

\section{Results and Discussion}

\subsection{The Risk Equation}

We start by the risk equation. In table 2 the dependent variable is a dummy for whether bank b's average risk on the product operation (standard and payroll loans) is above the median risk for the whole sample (January 2003 to June 2005) The main hypothesis is tested in column (1). The sample is restricted to 5 months before the decision and 5 months after the decision The coefficient associated with the difference-in-difference regressor $\left(\beta_{3}\right)$ is 0.357 , and it is quite precisely estimated (it is significant at the $1 \%$ level). This means that, relative to standard loans, the probability that the operation on payroll loans was above the median risk increased. The model is non-linear and there is no immediate way to interpret "above the median risk" is an economically meaningful way, so it is difficult to evaluate this coefficient quantitatively. One can, however, state that, qualitatively, risk perception on payroll loans increases in period following the court decision. The probability of the average risk on the banks' portfolio being above the the median decreases over the sub-sample period, for both loan (coefficient on Judicial Decision, -0.391). However, it decreases much less for payroll deduction loans, only - 0.184. Expansion in the number of operations is associated with less risk (a 1\% increase in the number of operations decreases the probability of being above the median in roughly $15.4 \%$ ), which is likely to indicate that a larger number of operations (and probably a lower average size) provide better diversification, although this result is not robust to different sub-samples. 
Dependent Variable: dummy for average risk above median

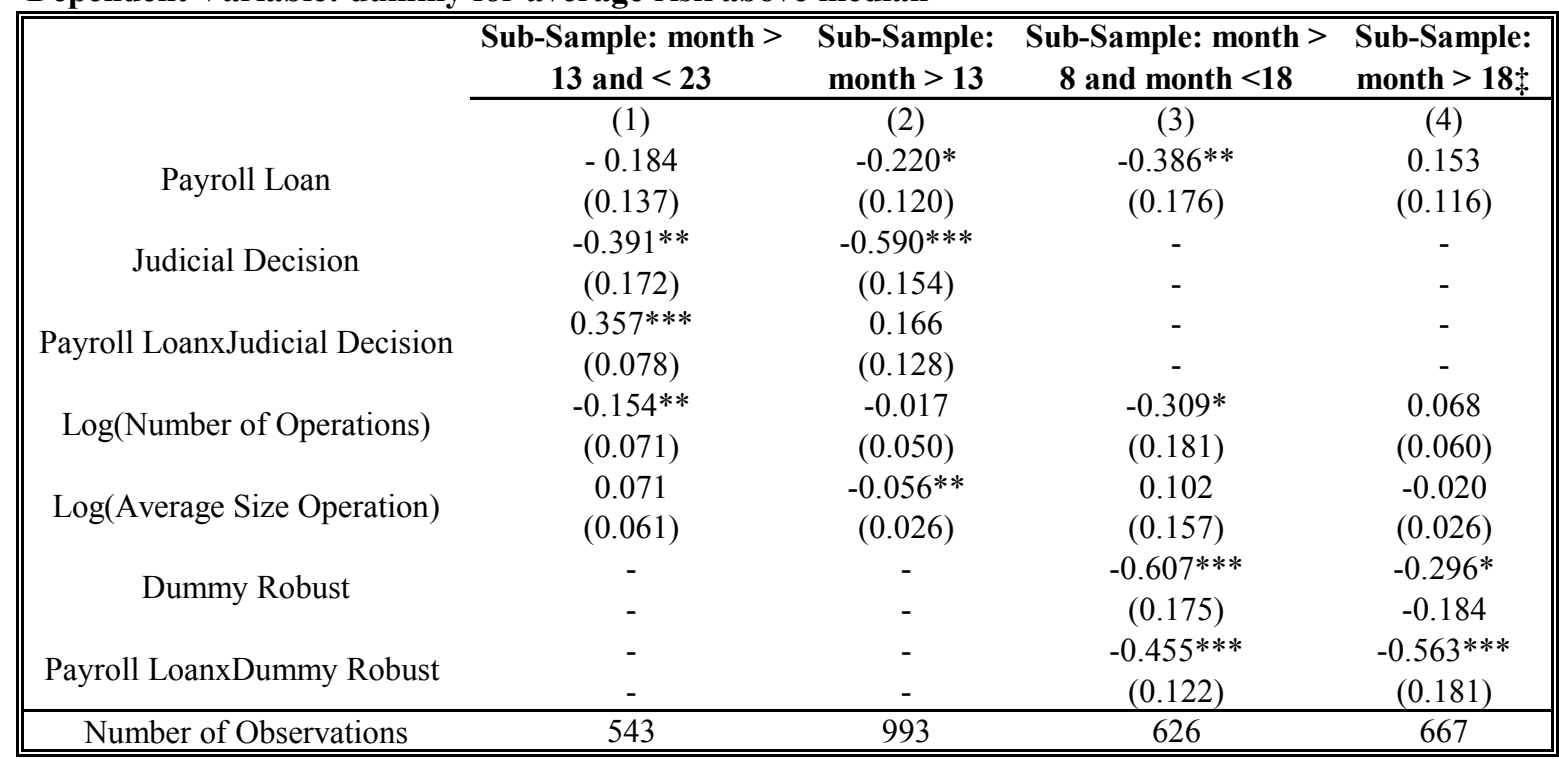

TABLE 2: Source: Banco Central do Brasil. Logit marginal effects estimates. Robust standard errors in parentheses. Control Group: Loans without Payroll Deduction. Weighted by Size of Banks operation. *** = Difference between sub-samples in estimated coefficient statatistically significant at the $1 \%$ level, $* *=5 \%$ level, $*=10 \%$ level. Bank and month dummies included. Judicial decision taking effect on July/2004 (month 12). $\dagger$ Dummy if month $>13, \ddagger$ Dummy if month $>24$

Although month specific dummies are included, it can always be the case that, for some unaccounted reason, risk perception was decreasing less for payroll deduction loans relative to plain personal loans, and this had nothing to do with the court ruling. For this reason, we first expand the period under consideration to all months after the law regulating payroll loans passed through congress. If the estimated difference-in-difference had nothing to do with the judicial decision, one would expect that the estimated coefficient on the interaction term to remain somewhat constant. As one can see in column (2), this is not case. Expanding the sample makes the "effect" of the judicial decision decrease by half, and it is no longer statistically significant, although the sample is almost twice the size. Additionally, faux treatment dummies are specified, to check whether the same pattern occurs if we consider artificial "treatment" dates. In column (4), the fake treatment is month 25 , and the sample is restricted on purpose to exclude the months before the judicial decision The estimated fake "difference-in-difference" coefficient has a reverse sign, and it is well estimated. If anything, the discrepancy between standard and payroll loans was the opposite for this sub-sample. Finally, 
the fake treatment period is put on month 14 , and the sample is restricted to months before the judicial decision (column (3)). Again, the coefficient has the opposite sign, i.e., risk increases in standard loans relative to payroll loans in this sub-sample with a fake treatment period at 14. Most likely, this captures the effect of the bill regulating payroll loans passing through congress.

Results are similar when risk is measured by the average risk rating on the banks' portfolio (see table 3). There are two differences though. First, we difference the log of the data to eliminate for fixed-effects. ${ }^{34}$ Second, with average risk rating as the dependent variable one has to account for the possibility that the dependent variable has persistence over time. For this reason, several different specifications are applied. First, an OLS model is used in which the first and the second lags of the dependent variable are included as explanatory variables. The standard errors of the estimated coefficients are corrected for between panel correlation and within panel autocorrelation. Again, banks' risk perception on payroll loans increased relative to standard loans: the estimated coefficient on the difference-in-difference parameters is 0.014, and it is significant at the 1\% level (column (1)). Economically, risk perception increased in payroll loans by roughly 1.4 percentage points. In column (2), a model for the dynamics of the errors term is imposed, and the parameters are estimated by a Feasible Generalized Least Squares (FGLS) procedure. The results for the parameter of interest $\left(\beta_{3}\right)$ are exactly the same.

\footnotetext{
${ }^{34}$ This is tantamount to controlling for fixed effects, and should be the prefered procedure. When the dummy for risk above median is used as a dependent variable, it is not natural to first-difference the data, and therefore bank dummies are included. See Woodridge [2002].
} 
Dependent Variable: $\Delta \log ($ Average Risk)

\begin{tabular}{|c|c|c|c|c|c|c|}
\hline & $\begin{array}{c}\text { Sub-Sample: } \\
\text { month }>13 \\
\text { and }<23 \dagger\end{array}$ & $\begin{array}{c}\text { Sub-Sample: } \\
\text { month }>13 \\
\text { and }<23+\end{array}$ & $\begin{array}{c}\text { Sub-Sample: } \\
\text { month }>13 \\
\text { and }<23+ \\
\end{array}$ & $\begin{array}{l}\text { Sub-Sample: } \\
\text { month }>13\end{array}$ & $\begin{array}{c}\text { Sub-Sample: } \\
\text { month }>8 \text { and } \\
<18 \$ \%\end{array}$ & $\begin{array}{l}\text { Sub-Sample: } \\
\text { month }>18 \%\end{array}$ \\
\hline \multirow{3}{*}{ Payroll Loan } & (1) & (2) & (3) & (4) & (5) & (6) \\
\hline & $-0.010 * *$ & $-0.006^{* *}$ & $-0.012 * *$ & $-0.013^{*}$ & 0.002 & 0.002 \\
\hline & $(0.004)$ & $(0.003)$ & $(0.005)$ & $(0.007)$ & $(0.004)$ & $(0.006)$ \\
\hline \multirow[t]{2}{*}{ Judicial Decision } & $0.009^{*}$ & 0.007 & -0.001 & 0.001 & - & - \\
\hline & $(0.005)$ & $(0.005)$ & $(0.007)$ & $(0.009)$ & - & - \\
\hline \multirow[t]{2}{*}{ Payroll LoanxJudicial Decision } & $0.014 * * *$ & $0.014 * * *$ & 0.009 & 0.006 & - & - \\
\hline & $(0.006)$ & $(0.005)$ & $(0.006)$ & $(0.008)$ & - & - \\
\hline \multirow[t]{2}{*}{$\Delta \log ($ Average Risk) $t-1$} & $0.544 * * *$ & $0.499 * * *$ & $0.497 * * *$ & $0.493 * * *$ & $0.460 * * *$ & $0.505 * * *$ \\
\hline & $(0.101)$ & $(0.030)$ & $(0.030)$ & $(0.009)$ & $(0.016)$ & $(0.012)$ \\
\hline \multirow[t]{2}{*}{$\Delta \log ($ Average Risk) $t-2$} & 0.008 & 0.002 & - & - & - & - \\
\hline & $(0.101)$ & $(0.024)$ & - & - & - & - \\
\hline \multirow[t]{2}{*}{$\Delta \log ($ Number of Operations) } & 0.073 & $0.065 * * *$ & $0.073 * * *$ & $0.025 * * *$ & $0.037 * * *$ & $0.022 * * *$ \\
\hline & $(0.090)$ & $(0.010)$ & $(0.010)$ & $(0.005)$ & $(0.006)$ & $(0.007)$ \\
\hline \multirow[t]{2}{*}{$\Delta \log ($ Average Size Operation $)$} & $0.103^{* *}$ & $0.008^{* * *}$ & $0.018^{* * *}$ & $0.002 * *$ & -0.000 & $0.002 * *$ \\
\hline & $(0.004)$ & $(0.002)$ & $(0.004)$ & $(0.001)$ & $(0.001)$ & $(0.001)$ \\
\hline \multirow[t]{2}{*}{ Dummy Robust } & - & - & - & - & 0.002 & $-0.015^{*}$ \\
\hline & - & - & - & - & $(0.005)$ & $(0.009)$ \\
\hline \multirow{2}{*}{ Payroll LoanxDummy Robust } & - & - & - & - & -0.006 & $-0.017 * *$ \\
\hline & - & - & - & - & $(0.004)$ & $(0.008)$ \\
\hline Number of Observations & 543 & 543 & 543 & 993 & 626 & 667 \\
\hline
\end{tabular}

TABLE 3: Source: Banco Central do Brasil. Robust standard errors in parentheses. Control Group: Loans without Payroll Deduction. Weighted by Size of Banks operation. $* * *=$ Difference between sub-samples in estimated coefficient statatistically significant at the $1 \%$ level, $* *=5 \%$ level, $*=10 \%$ level. Month dummies included. Judicial decision taking effect on July/2004 (month 12). $\dagger=$ OLS estimates, with standard error of estimated coefficients corrected for between panel correlation and within panel autocorrelation using the Praiss-Winsten procedure. $\%=$ Dummy if month $>13$. $\bullet=$ dummy if month $>24$. $\ddagger=$ Feasible Generalized Least Squares with AR(1) model for within panel auto-correlation. $+=$ IV estimates with Deltalog(Average Risk) $t$. 2 as instrument for DeltaLog(Average Risk) $t-1$

There is, however, the possibility that there is persistence both in the process of the dependent variable and the unobserved factors that affect risk (the error term). Columns (1) and (2) suggest the second lag of the $\Delta \log$ (Average Risk) does not belong to the equation. Therefore, it arises as a natural instrument for $\Delta \log$ (Average Risk) ${ }_{t-1}$ under the identifying assumption the error term has only one period persistence. ${ }^{3536}$ Now, there

\footnotetext{
${ }^{35}$ Exactly because the second lag does not appear to be a explanatory variable, using further lags as instrument would not be awarranted since they do not arise naturally as shifts to the endogenous variable that are not related to the unobserved determinants of risk perception (the error term).

${ }^{36}$ As with any identifying assumption it is impossible to verify it empirically. Since the data is in the first-difference of logs, there is no compelling reason why adjustments to unobserved shocks to risk would take more than a month to be incorporated to the banks' credit rating decision.
} 
is not enough independent variation to estimate the parameter of interest: the $p$-value of estimation is roughly $13 \%$. The difference-in-difference coefficient is, nonetheless, still positive, although with a lower magnitude (0.009). Columns (4) to (6) present the same robustness checks as in table 3. Results, and corresponding interpretations, are qualitatively similar.

Results could be driven by two factors unrelated to the STJ ruling, but implied by heterogeneity in the dynamics of the treatment and control groups. First, as table 1 shows, standard loans are, as expected, riskier than payroll loans. If there are general institutional advances in credit markets during the period, and if there are decreasing returns in risk improvement, then one should observe a decrease in riskiness of standard vis-à-vis payroll loans because the former started at a higher level of risk. However, if this was the case, one would expect that the same pattern would emerge for all subsamples of whole period. As columns (3) and (4) in table 2 indicate, risk perception on payroll loans decreases vis-à-vis standard loans in the periods before and after the STJ ruling. Same is true in table 3 (columns (5) and (6)).

Second, as Figure 4 shows, payroll loans boomed during the period, possibly due to the approval of the December 2003 law. Expansions might be risk-increasing, i.e., the marginal borrower may be worse than the inframarginal ones. If this is the case, the pool of borrowers on payroll lending would be changing, compared to standard lending, in such a way that would produce the result regardless of the court ruling. There are, however, at least two reasons why this story cannot rationalize the results. First, the number of operations is controlled for. In table 3, for example, changes in the log of average risk are explained by the court ruling with variation above and beyond changes in log of number and average size of operations. Indeed, since the model is in first differences, results are not only controlled for the fact that larger banks might have lower risk borrowers, but also for within bank expansions of payroll vis-à-vis standard operations. Second, the same argument as in the last paragraph applies. Figure 4 shows that payroll operations rose, relative to standard ones, throughout the period. Hence, if the changing pool of borrowers argument would apply, one should verify the same increase in riskiness of payroll vis-à-vis standard operations throughout the period. As columns (3) and (4) in table 2 and (5) and (6) in table 3 show, this does not seem to be the case. 


\subsection{The Quantity Equation}

The results for the quantity equation are presented in tables 4 and 5 .

\begin{tabular}{|c|c|c|c|c|c|}
\hline \multicolumn{6}{|c|}{ Dependent Variable: $\Delta \log ($ Amount of Loans) } \\
\hline \multirow{4}{*}{$\Delta \log ($ Amount of Loans) $t-1$} & $\begin{array}{c}\text { Sub-Sample: } \\
\text { month }>13 \text { and } \\
<23\end{array}$ & $\begin{array}{c}\text { Sub-Sample: } \\
\text { month }>13 \text { and }< \\
23\end{array}$ & $\begin{array}{c}\text { Sub-Sample: } \\
\text { month }>13 \text { and }< \\
23\end{array}$ & $\begin{array}{c}\text { Sub-Sample: month } \\
>13 \text { and }<23 \text { (IV } \\
\text { estimates) } \dagger\end{array}$ & $\begin{array}{c}\text { Sub-Sample: month } \\
>13 \text { and }<23 \text { (IV } \\
\text { estimates) } \dagger\end{array}$ \\
\hline & (1) & (2) & (3) & (4) & (5) \\
\hline & - & - & $0.346^{* * *}$ & $0.580 * * *$ & $0.586^{* *}$ \\
\hline & - & - & $(0.105)$ & $(0.225)$ & $(0.237)$ \\
\hline \multirow[t]{2}{*}{ Payroll Loan } & $0.065 * * *$ & $0.065 * * *$ & $0.044 * * *$ & $0.033^{*}$ & $0.032 *$ \\
\hline & $(0.017)$ & $(0.017)$ & $(0.014)$ & $(0.019)$ & $(0.019)$ \\
\hline \multirow[t]{2}{*}{ Judicial Decision } & $0.038^{* *}$ & 0.026 & $0.035^{* *}$ & $0.034^{* *}$ & $0.077^{*}$ \\
\hline & $(0.016)$ & $(0.018)$ & $(0.015)$ & $(0.016)$ & $(0.041)$ \\
\hline \multirow[t]{2}{*}{ Payroll LoanxJudicial Decision } & $-0.058 * *$ & $-0.058 * *$ & $-0.045^{* *}$ & $-0.038 * *$ & $-0.037^{*}$ \\
\hline & $(0.024)$ & $(0.025)$ & $(0.021)$ & $(0.022)$ & $(0.022)$ \\
\hline \multirow[t]{2}{*}{$\Delta \log ($ Average Risk) } & 0.077 & 0.026 & 0.072 & 0.079 & 0.029 \\
\hline & $(0.468)$ & $(0.446)$ & $(0.437)$ & $(0.420)$ & $(0.404)$ \\
\hline \multirow[t]{2}{*}{$\Delta \log ($ Average Risk) $t-1$} & $-0.308^{*}$ & -0.287 & -0.289 & -0.225 & -0.183 \\
\hline & $(0.180)$ & $(0.202)$ & $(0.187)$ & $(0.218)$ & $(0.240)$ \\
\hline Date Dummy? & no & yes & no & no & yes \\
\hline Number of Observations & 507 & 507 & 507 & 507 & 507 \\
\hline
\end{tabular}

TABLE 4: Source: Banco Central do Brasil. OLS estimates. Robust standard errors in parentheses. Control Group: Loans without Payroll Deduction. Weighted by Size of Banks operation. $* * *=$ Difference between sub-samples in estimated coefficient statatistically significant at the $1 \%$ level, $* *=5 \%$ level, $*=10 \%$ level. Bank dummies included. Judicial decision taking effect on July/2004 (month 18). $\uparrow$ Instrument: second lag of $\Delta \log ($ Amount of Loans)

Column (1) presents the simplest possible model: OLS omitting $\Delta \log ($ Amount of Loans $)_{t-1}$ as an explanatory variable and no period dummies. As expected, operations of payroll loans are larger $(6.5 \%$ more $)$, and quantities of both standard and payroll loans appear to be increasing over time (coefficient on Judicial Decision, 3.8\% on average in the sub-period between February 2004 and October 2004), as figure 4 suggested. Despite the markedly different slopes of standard and payroll loans, the judicial decision did have a negative effect on payroll loans: relative to standard loans, payroll loans decrease when one compares before and after the court ruling. Indeed, after controlling for average risk, payroll loan quantities decreased $5.8 \%$, between the 5 month sub-period before the court ruling and the 5-month sub-period after the ruling. Inclusion of period dummies hardly changes the results (column (2)). Results are, however, slightly different when the lag of the dependent variable in included: one can see (column (3)) that part of the difference-indifference coefficient was capturing some variation of the $\Delta \log$ (Amount of Loans) $)_{t-1}$. Results, however, remain considerably similar. 
The presence of the lag of the dependent variable poses again the challenge of searching for exogenous variation to estimate the coefficient associated with $\Delta \log$ (Amount of Loans) ${ }_{t-1}$ since there could also be persistence on the error term. Again, we follow the strategy of using the second lag $(\Delta \log$ (Amount of Loans) ${ }_{t-1}$ ) as an instrument. Columns (4) and (5) present the results. It does appear that part of the estimated coefficient in columns (1) to (3) are unduly capturing variation due to omission of explanatory variables (which are in the dynamics of the error term). The effect, however, still survives: in the most unfavorable specification, there is $3.7 \%$ difference in the trends of standard and payroll loans when periods before and after the court ruling is considered. This result is not terribly well estimated, but one could reject the null that it is zero at the $5.8 \%$ level. (column (5)).

Table 5 presents different specifications. In column (1) and (3), standard error estimates are corrected for between panel correlation and within panel auto-correlation. Notice that the estimates of the diff-in-diff parameters are even more precisely estimated. When a FGLS procedure is used, results are similar (column (2)). These results do not account for the possible omitted variable bias due to the presence of $\Delta \log (\text { Amount of Loans })_{t-2}$, but do suggest that the statistical significance in table 4 is not due to under-estimation of standard errors. Column (4) checks the robustness of the results in the same spirit as in tables 2 and 3: it appears that the estimated diff-in-diff coefficient is not due to a long term pattern over the whole sample period. When the fake treatment period 25 is used, and the sample is restricted to after the court ruling, the result disappear. Similar robustness results hold for the whole period and for only the period before the court ruling. 
Dependent Variable: $\Delta \log ($ Amount of Loans)

\begin{tabular}{|c|c|c|c|c|}
\hline & $\begin{array}{c}\text { Sub-Sample: } \\
\text { month }>13 \text { and } \\
<23 \dagger\end{array}$ & $\begin{array}{c}\text { Sub-Sample: } \\
\text { month }>13 \\
\text { and }<23 \ddagger\end{array}$ & $\begin{array}{c}\text { Sub-Sample: } \\
\text { month }>13 \\
\text { and }<23 \dagger\end{array}$ & $\begin{array}{l}\text { Sub-Sample: } \\
\text { month }>18 \%\end{array}$ \\
\hline \multirow{3}{*}{$\Delta \log ($ Amount of Loans $) t-1$} & (1) & (2) & (3) & (4) \\
\hline & 0.222 & $0.150 * * *$ & 0.189 & - \\
\hline & $(0.118)$ & $(0.054)$ & $(0.182)$ & - \\
\hline \multirow{2}{*}{ Payroll Loan } & $0.052 * * *$ & $0.057 * * *$ & $0.053 * * *$ & $0.036^{*}$ \\
\hline & $(0.017)$ & $(0.019)$ & $(0.017)$ & $(0.021)$ \\
\hline \multirow{2}{*}{ Judicial Decision } & $0.035 * *$ & $0.057 * * *$ & $0.057 * * *$ & - \\
\hline & $(0.017)$ & $(0.022)$ & $(0.019)$ & - \\
\hline \multirow{2}{*}{ Payroll LoanxJudicial Decision } & $-0.051 * * *$ & $-0.053 * *$ & $-0.052 * * *$ & - \\
\hline & (0.018) & $(0.024)$ & $(0.018)$ & - \\
\hline \multirow{2}{*}{$\Delta \log ($ Average Risk) } & 0.033 & 0.067 & 0.003 & -0.082 \\
\hline & $(0.144)$ & $(0.093)$ & $(0.151)$ & $(0103)$ \\
\hline \multirow{2}{*}{$\Delta \log ($ Average Risk $) t-1$} & $-0.280 * *$ & $-0.273 * * *$ & $-0.278^{*}$ & $-0.161^{*}$ \\
\hline & $(0.141)$ & $(0.093)$ & $(0.154)$ & $(0.098)$ \\
\hline \multirow{2}{*}{ Dummy Robust } & - & - & - & 0.020 \\
\hline & - & - & - & $(0.021)$ \\
\hline \multirow{2}{*}{ Payroll LoanxDummy Robust } & - & - & - & 0.015 \\
\hline & - & - & - & $(0.034)$ \\
\hline Date Dummy? & no & yes & yes & yes \\
\hline Number of Observations & 507 & 507 & 507 & 665 \\
\hline
\end{tabular}

TABLE 5: Source: Banco Central do Brasil. OLS estimates. Robust standard errors in parentheses. Control Group: Loans without Payroll Deduction. Probability-weighted by Size of Bank operation. $* * *=$ Difference between sub-samples in estimated coefficient statatistically significant at the $1 \%$ level, $* *=5 \%$ level, $*=10 \%$ level. Bank dummies included. Judicial decision taking effect on July/2004 (month 18). † Standard Error of Estimated Coefficients corrected for between panel correlation and within panel autocorrelation using the Praiss-Winsten procedure. + : Feasible Generalized Least Squares assuming errors within panels follow an AR(1) process. \% = Dummy Robust $=1$, if month $>18$, most favorable model: FGLS assuming errors within panels follow an AR(1) process.

\subsection{The Pricing Equation}

The effect of the court ruling on the interest rates of payroll loans can be found in table 6. A couple of comments are necessary. Differently from the quantity regression, the number of operations and the average size of the operation are included. We do so because there might be (dis)economies of scale involved in granting loans. Both variables are lagged one period to mitigate the possibility of capturing demand side effects. Second, it is important once again to emphasize that the data on prices is problematic, specially for interpretation on levels. Taking the log and first-differencing the data ameliorate somehow the problems with levels but do not solve it. 
Interpretation on changes, however, is less troublesome and we proceed by doing so, specially since the results with interest rates are consistent with the results on quantities and risk perception.

Dependent Variable: $\Delta \log (i n t e r e s t$ rate)

\begin{tabular}{|c|c|c|c|c|c|}
\hline & $\begin{array}{c}\text { Sub-Sample: } \\
\text { month }>13 \text { and } \\
<23 \dagger \\
\end{array}$ & $\begin{array}{c}\text { Sub-Sample: } \\
\text { month }>13 \text { and } \\
<23 \dagger\end{array}$ & $\begin{array}{c}\text { Sub-Sample: } \\
\text { month }>13 \\
\text { and }<23\end{array}$ & $\begin{array}{c}\text { Sub-Sample: } \\
\text { month }>13 \text { and } \\
<23 \dagger\end{array}$ & $\begin{array}{c}\text { Sub-Sample: } \\
\text { month }>18 \dagger \%\end{array}$ \\
\hline & $(1)$ & (2) & (3) & (4) & $(5)$ \\
\hline$\Delta \log ($ interest rate) $t-1$ & 0.019 & 0.008 & 0.008 & - & - \\
\hline$\Delta \log ($ interest rate) $t-1$ & $(0.193)$ & $(0.193)$ & $(0.039)$ & - & - \\
\hline Payroll Loan & $\begin{array}{c}-0.063 * * * \\
(0.020)\end{array}$ & $\begin{array}{c}-0.061 * * * \\
(0.020)\end{array}$ & $\begin{array}{l}-0.061 \\
(0.047)\end{array}$ & $\begin{array}{c}-0.062 * * * \\
(0.021)\end{array}$ & $\begin{array}{l}-0.019 \\
(0.025)\end{array}$ \\
\hline Judicial Decision & $\begin{array}{c}-0.075 * * * \\
(0.028)\end{array}$ & $\begin{array}{c}-0.143 * * * \\
(0.035)\end{array}$ & $\begin{array}{c}-0.143 * * \\
(0.063)\end{array}$ & $\begin{array}{c}-0.095 * * * \\
(0.031)\end{array}$ & - \\
\hline Payroll LoanxJudicial Decision & $\begin{array}{c}0.073 * * * \\
(0.024)\end{array}$ & $\begin{array}{c}0.071 * * * \\
(0.024)\end{array}$ & $\begin{array}{c}0.071 \\
(0.060)\end{array}$ & $\begin{array}{c}0.071 * * * \\
(0.026)\end{array}$ & $\begin{array}{l}- \\
-\end{array}$ \\
\hline$\Delta \log ($ Average Risk) & $\begin{array}{l}-0.464 \\
(0.315)\end{array}$ & $\begin{array}{l}-0.475 \\
(0.334)\end{array}$ & $\begin{array}{l}-0.475 \\
(0.273)\end{array}$ & $\begin{array}{c}-0.480 \\
(-0.325)\end{array}$ & $\begin{array}{c}0.408 \\
(0.570)\end{array}$ \\
\hline$\Delta \log ($ Average Risk) $t-1$ & $\begin{array}{c}0.430^{* *} \\
(0.221)\end{array}$ & $\begin{array}{l}0.410^{*} \\
(0.239)\end{array}$ & $\begin{array}{l}0.410^{*} \\
(0.379)\end{array}$ & $\begin{array}{c}0.423 * * \\
(0.179)\end{array}$ & $\begin{array}{c}0.363 \\
(0.582)\end{array}$ \\
\hline $\log ($ Average Size of Operation $t-1)$ & $\begin{array}{l}-0.004 \\
(0.098)\end{array}$ & $\begin{array}{l}-0.016 \\
(0.103)\end{array}$ & $\begin{array}{l}-0.016 \\
(0.182)\end{array}$ & $\begin{array}{l}-0.011 \\
(0.101)\end{array}$ & $\begin{array}{l}-0.134 \\
(0.087)\end{array}$ \\
\hline $\log ($ Number of Operations $t-1)$ & $\begin{array}{c}0.049 \\
(0.024)\end{array}$ & $\begin{array}{c}0.045 \\
(0.052)\end{array}$ & $\begin{array}{c}0.045 \\
(0.044)\end{array}$ & $\begin{array}{c}0.045 \\
(0.053)\end{array}$ & $\begin{array}{c}-0.036^{* * *} \\
(0.013)\end{array}$ \\
\hline Dummy Robust & - & - & - & - & $\begin{array}{l}0.080^{*} \\
(0.47)\end{array}$ \\
\hline Payroll LoanxDummy Robust & - & - & - & - & $\begin{array}{c}0.057 \\
(0.058)\end{array}$ \\
\hline Date Dummy? & no & yes & yes & yes & no \\
\hline Number of Observations & 507 & 507 & 507 & 507 & 665 \\
\hline
\end{tabular}

TABLE 6: Source: Banco Central do Brasil. OLS estimates. Robust standard errors in parentheses. Control Group: Loans without Payroll Deduction. Weighted by Size of Banks operation. $* * *=$ Difference between sub-samples in estimated coefficient statatistically significant at the $1 \%$ level, $* *=5 \%$ level, $*=10 \%$ level. Bank dummies included. Judicial decision taking effect on July/2004 (month 18). $\uparrow$ Standard Error of Estimated Coefficients corrected for between panel correlation and within panel autocorrelation using the Praiss-Winsten procedure. $\%=$ dummy $=1$ if month $>24$.

Column (1) shows the OLS results when the lag of the dependent variable is included, but not the period dummies. Consistent with the quantity and risk perception results, and with the perception of important market participants, the court ruling appears to have induced an increase in the interest rate charged on payroll loans. After controlling for number of operations, average size of operations and risk, there is a marked difference $(7.3 \%)$ between the trends of interest rates on payroll and standard loans before and after the court ruling. Consistent with the general perception in the market, interest rates on payroll loans are lower than those on standard loans 
(6.3\%). Estimates suggest risk perception does indeed affect interest rate as expected: while one cannot reject the null hypothesis that contemporaneous changes in risk perception affect interest rates, one period lagged increases in risk perception does induce an increase in prices of loans. After standard errors of estimation are corrected for between panel correlation and within panel serial correlation, the lag of the dependent variable does not appear to belong to the equation. This renders results less vulnerable to dynamic panel bias.

Columns (2), (3) and (4) present slightly different specifications. Most noteworthy is column (3), in which the OLS standard errors of estimation are not corrected. Here, one cannot reject the null hypothesis that there are not difference between standard and payroll loans with respect to the court ruling. The estimates suggest that correction on the standard deviation provides better (more precisely) estimates for the diff-in-diff parameter. Column (5) presents the same robustness check as in all other tables, and it is again consistent with the previous results.

\section{Conclusion}

The results in this paper suggest the conjecture, of some market participants, that the June 2004 court ruling had an adverse effect on the market performance of payroll loans. Results arise, and are consistent among each other, for risk perception, quantity of loans, and interest rates, with the data caveat for the latter. Data suggests that the ruling increase risk perception on payroll loans, which in turn led banks to restrict quantity and increase interest rates.

These results are far from obvious. Several key market players anticipated them, but not all. It could have been that lenders had ignored the ruling. As Figure 4 eloquently suggests, the court ruling did not prevent the boom of payroll loans. It did, however, abate it, and made it such that terms to borrowers were worse.

This paper provides some evidence on the missing link of the institutionseconomic performance nexus literature: the micro evidence. Far from contradicting the literature, our results corroborate it with evidence drawn from the unit of decision making: lenders in this case. It reinforces the policy recipes already implied by the literature. Better protection from expropriation most likely increases general welfare, as it improves market performance in infor- 
mationally and incentive problematic markets, such as the credit market.

\section{References}

Acemoglu, Daron, Simon Johnson, and James Robinson, 2001, "The Colonial Origins of Comparative Development: An Empirical Investigation," The American Economic Review, December, pp. 1369-1401.

Altunbas, Yener, Lynne Evans and Philip Molyneux, 2001, "Bank Ownership and Efficiency" Journal of Money, Credit and Banking, Vol 33, No.4, 926-954.

Arellano, Manuel, and Stephen Bond, 1991, "Some Tests of Specification for Panel Data: Monte Carlo Evidence and an Application to Employment Equations," The Review of Economic Studies, Vol. 58, pp. 277-297.

Djankov, Simeon, Rafael La Porta, Florencio Lopez-de-Silanes, and Andrei Shleifer, 2003, "Courts," The Quarterly Journal of Economics, May, pp. 453-507.

Dubey, Martin, John Geanakoplos, and Pradeep Shubik, 2005, "Default and Punishment in General Equilibrium," Econometrica, Vol. 73, No.1, pp. $1-37$.

Jornal Valor Econômico, edition 07/02/2004, 08/13/2004

King, Robert, and Ross Levine, 1993, "Finance and Growth: Schumpeter Might be Right," The Quarterly Journal of Economics, August, pp. 717-737.

La Porta, Rafael, Florencio Lopez-de-Silanes, Andrei Shleifer, and Robert Vishny, 1997, "Legal Determinants of External Finance," The Journal of Finance, July, pp. 1131-1150.

La Porta, Rafael, Florencio Lopez-de-Silanes, Andrei Shleifer, and Robert Vishny, 1998, "Law and Finance," The Journal of Political Economy, December, pp. 1113-1155.

Levine, Ross, 1998, "The Legal Enviroment, Banks, and Long-Run Economic Growth,", The Journal of Money, Credit, and Banking, August. 
Levine, Ross, and Sara Zervos, 1998, "Stock Markets, Banks, and Economic Growth," The American Economic Review, June, pp. 537-558.

North, Douglas, 1994, "Economic Performance Through Time" American Economic Review, vol. 84(3), pages 359-68.

Pinheiro, Armando Castelar and Célia Cabral, 1998, "Credit Markets in Brazil: The Role of Judicial Enforcement and Other Institutions" Ensaios BNDES, nr. 9.

Sapienza, Paola, 2002, "The Effects of Government Ownership on Bank Lending" Journal of Financial Economics, vol. 72(2), pages 357-384.

Universo on Line, edition 07/04/2004, http://an.uol.com.br/2004/jul/04/0eco.htm.

Wooldridge, Jeffrey, 2002, Econometric Analysis of Cross Section and Panel Data, Cambridge: The MIT Press. 